\title{
Screening obesity in Adolescents
}

\author{
S. Jain ${ }^{1}$, B.Pant ${ }^{2}$, H. Chopra ${ }^{3}$, R. Tiwari ${ }^{4}$ \\ 1.Assoc. professor, Department of Community Medicine L.L.R.M.M.C.,Meerut \\ 2.Professor Department of Community Medicine Subharati Medical College 3. Professor Department of \\ Community Medicine L.L.R.M.M.C.,Meerut 4. Statistician and Assist. Professor Subharati Medical College
}

\begin{abstract}
Summary: Global health status is showing its alarming concern towards emergence of non communicable diseases, which is taking major death toll. Obesity, being the most common risk factor for prevalent NCDs, has now become a major public health issue. Even in developing countries like India, obesity has spread its roots in children and adolescents, making them much more prone for NCDs. There is urgent need of screening such children at school level, so that timely intervention can be taken. The present school based cross sectional study was done among affluent adolescents with an objective to assess the magnitude of obesity in adolescents, with the help of three reference standards based on BMI criteria. All the three standards used were comparable to screen obesity by Anova test of significance. Study recommends to use EHPA charts in school health check ups, to detect both over and undernutrition in adolescents .
\end{abstract}

Key words - Overweight, Obesity, Adolescents

\section{Introduction}

Global status report by WHO shows that biggest cause of death worldwide is, underlying non communicable diseases ${ }^{1}$. Paradoxically coexisting with under nutrition in developing countries, the increasing prevalence of overweight and obesity in children and adults has been associated with many chronic diseases ${ }^{2}$. In India situation is very grim ,indicating high rise of overweight and obese individuals, who have double chance to develop non communicable diseases ${ }^{1,3}$. Overweight children have double chances to become obese adult than normal children ${ }^{3}$. Obesity is harder to treat in adults than in children ${ }^{4,5}$.So Obesity prevention is, nowadays a major public health priorty.

Adolescence is characterized by an exceptionally rapid rate of growth and is often variable in individuals due to its dependence on genetic, hormonal and nutritional factors ${ }^{5,6}$. Thus it is required to monitor their growth parameter. It is often felt that health of adolescents is often neglected due to lack of awareness, busy work schedule , and poor compliance .

\section{AIMS AND OBJECTIVES}

. To search an appropriate, easy, and acceptable screening tool for assessing the overweight and obesity in adolescents at school level.

\section{Methodology}

It was a cross sectional study done among adolescents of 6 affluent public schools of Meerut district, having almost similar fee structure from october2003 to march 2004. The schools were selected by using simple random sampling procedure, taking schools within 10 kilometer distance from medical college. Consent was obtained from all the principals of the schools. Sample size of 2785 was calculated by taking $15 \%$ relative error for qualitative data on prevalence of $6 \%$, in affluent adolescents ${ }^{7}$.All students aged 10-16 years from class 5 to 11 were selected.

A detailed proforma comprising of complete information about their personal habits, dietary intake etc, was given to the each participant, and was collected after two days .On the day of collection of proforma ,each participant was examined and followed by the measurement of weight and height using, standard measure of electronic weighing scale to nearest $100 \mathrm{gm}$ and Height measuring stand to nearest $0.1 \mathrm{~cm}$. A complete data was available from 2570 students giving dropout of $7.7 \%$. So from each school 519, 434, 441, 509, 458 and 424 students were included in the study. Data was analyzed for overweight and obesity by the help of BMI values comparing with reference standards for BMI cut off criteria for overweight and obesity in adolescents .

In the present study following three reference standards were used to assess obesity in adolescents.

- International BMI cut off points for overweight and obesity in children between 2 to 18 years are prepared by taking data of children of various countries ${ }^{8}$.and is accepted World wide .( Tim J Cole etal. $)^{8}$

- NHANES I data- Age\& sex wise reference $85^{\text {th }}$ percentile and $95^{\text {th }}$ percentile of BMI, used to assess overweight and obesity. ${ }^{9}$ 
- Eliz health pathway for adolescents ${ }^{6}$, which can be used as adolescent health card. EHPA ${ }^{6}$ is a new approach to quickly assess growth of adolescents and it shows under weight adolescents as well as overweight. By this method we can directly read BMI from the chart by marking weight and height on the same chart. ( Figure -1)

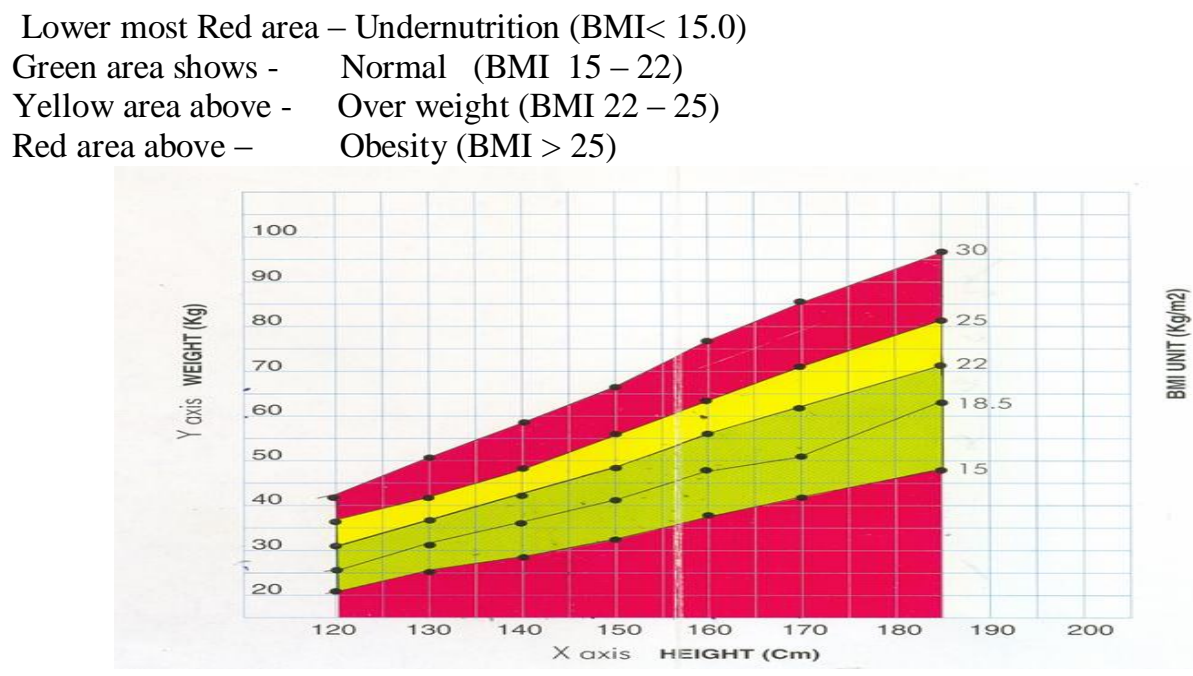

(Figure-1)

\section{Results \& Discussion}

The prevalence of obesity in adolescents of public schools of Meerut was found to be $8.4 \%, 8.6 \%$ and $8.8 \%$ respectively by BMI criteria Tim J Col et al. ${ }^{8}$, NHANES-I ${ }^{9}$ and Eliz Health Pathway ${ }^{6}$ (Table $1 \& 2$ ) which is comparable to findings by Kapil ${ }^{7}$ and Vedavati ${ }^{10}$ et al and higher than the findings of Bharati etal ${ }^{11}$. On this basis Eliz health pathway of adolescent (Figure-1) is a simple tool to asses nutritional status of an adolescents even if he or she is under nourished or over nourished. It also shows a high prevalence of under nourished adolescent girls (7.7\%) and boys (9.3\%) along with normal, over weight and obese adolescents. (Table $3 \& 4$ ). All the three methods when compared by Anova Test, showed no statistically significant difference both among boys and girls.

The prevalence of obesity was higher in males than females comparable to Kapil et al ${ }^{7}$ but Vedavathi ${ }^{10}$ showed higher prevalence in males. .Maximum obesity was seen in 10-12 year of age in both the sexes comparable to Kapil etal ${ }^{7}$. This sudden transition in early adolescent,s health may develop some nutritional problem in them. At this stage this is very important to screen them for such problems and guide them timely to inculcate healthy habits .There are observations suggest that $80 \%$ of overweight adolescents will become obese adults $^{12}$. Present study reveals poor nutritional status among affluent adolescents being, 7.7\% among girls and 9.34\% among boys by the help of EHPA, which is quiet high.

Adolescence being the most important transition phase of life. This phase of life shows increase in adipose tissue and overall weight gain during the pubertal growth spurt. So some time due to marked variation in growth a pattern; the parameters to assess the normal or health growth of an adolescent may be misleading. The parameter of small children can not be comparable with adolescents to assess their standard weight and height. Even tricep skin fold thickness, a parameter to assess obesity in adolescents, is often variable with sexual maturity ratings. Fat is redistributed during growth, varies as per age sex and sexual maturity onset.So BMI is most reliable, WHO approved parameter to assess obesity also used by Bharati et $\mathrm{al}^{11}$ and Raj $\mathrm{M}$ etal ${ }^{12}$. The present study various BMI cut off criteria used, to assess the obesity, are comparable by anova test giving $p>0.5$ both for boys and girls.. Eliz health pathway for adolescents is comparable with other reference standards BMI cut off points to assess the obesity in adolescents, giving an additional advantage of assessing underweight adolescents too. The chart used here is easy to interpret and does not require any calculations .

\section{Conclusion- .}

Prevalence of adolescents obesity especially in affluent population is an important public health issue. The present study reveals the high proprtion of overweight and obese adolescents. and also recommends that all school authorities should screen nutritional status of adolescents .Regulars health check ups can give alarming signals of upcoming chronic diseases. School authorities can do interventions like regular BMI monitoring by students themselves.. Adolescents should be informed in detail about risk for obesity and non communicable diseases . So that they can design their lifestyles in advance for healthy future. To motivate students with ideal 
Body mass index, or healthy status, should be awarded by school authorities .School libraries can display standard body weight height charts and waist - hip ratio .or Eliz health pathway for adolescents, to make our future generations aware about their fitness. "Some one has truly said: Anything measured gets corrected ."

\section{References}

[1]. Dobe M: Health promotion for NCD prevention ,IJPH, vol 56, Issue 3, Jul-Sept 2012

[2]. Thakkar HK Misra SK, Gupta SK, Kaushal SK,A study on prevalence of obesity among college going girls in Agra district UP,.IJCH, Vol 21-22, No 1,2, july 2009-june 2010, pg 61

[3]. 3 International Life Sciences Institutes, Preventing Childhood Obesity is a Current Research Focus : Initiatives Cooperate to Share Information and Stem Epidemic. The PAN Report : Physical Activity and Nutrition, USA, International Life Science Institute, 2000:vol2 p 5.

[4]. Styne DM, Childhood obesity and Adolescent obesity PCNA-2001, Vol-48, 823-847.

[5]. Shetty P.S. Childhood obesity in Developing societies, NFI Bulletin 1999, Vol 20, No-2, Page-4.

[6]. Elizabeth KE., A novel growth assesment chart for adolescencet, Indian Pediatrics 2001, Volume 38,No;9 Sep-1061-1064,

[7]. Kapil U, Singh P, Pathak P et-al Prevalence of obesity among affluent adolescent school children in Delhi, Indian Pediatrics 2002 Volume 39- May 17, Page 450-452.

[8]. Cole T.J. Bellizzi M.C. Flegal K.M, Diez W.H. Establishing standard definition for child overweight and obesity world wide : International survey B.M.J. $2002: 320-1240-3$.

[9]. Must A, Dallal G.E., Dietz W.H. 85th Percentile and 95th Percentile of Body Mass Index and Triceps skin fold thickness Reference data, American Journal of clinical Nutrition 1991 Volume 53 \& 54 pg 839 - 846 \& Page 773.

[10]. Vedavati S, Jay Shree S, Mohammad R. Prevalence of overweight and obesity in affluent adolescent girls in Chennai in 1981 and 1998 Indian Pediatrics vol. 40 April 17, 2003, Pg-332-335.

[11]. Bharati D R ,Deshmukh PR,Garg BS. Correlates of overweight and obesity among school going children of Wardha district,Central India.Ind J.of Med Res 127,June2008, pg539-543

[12]. Raj M ,Kumar R K. Obesity in children and adolescents:Indian J Med Res 132, November 2010, pg 598-607

(TABLE -1)

PREVELENCE OF OBESITY AND OVER WEIGHT BOYS

\begin{tabular}{|c|c|c||c|c|c|c|c|}
\hline Age & $\begin{array}{c}\text { No of } \\
\text { boys }\end{array}$ & Tim J. Cole Pts & $\begin{array}{c}\text { NHANES-1 } \\
\text { References }\end{array}$ & EHPA & Tim J. Cole & NHANES & EHPA \\
\hline 10 & 174 & $\begin{array}{c}29 \\
(16.7)\end{array}$ & $\begin{array}{c}31 \\
(17.8)\end{array}$ & $\begin{array}{c}29 \\
(16.7)\end{array}$ & $\begin{array}{c}39 \\
(22.4)\end{array}$ & $\begin{array}{c}38 \\
(21.8)\end{array}$ & $\begin{array}{c}36 \\
(20.7)\end{array}$ \\
\hline 11 & 309 & 33 & 34 & 32 & 46 & 46 & 46 \\
$(10.7)$ & $(11.0)$ & $(10.4)$ & $(14.9)$ & $(14.9)$ & $(14.9)$ \\
\hline 12 & 456 & 57 & 58 & 57 & 114 & 111 & 99 \\
& & $(12.5)$ & $(12.7)$ & $(12.5)$ & $(25)$ & $(24.3)$ & $(21.7)$ \\
\hline 13 & 411 & 36 & 38 & 37 & 81 & 80 & 81 \\
& & $(8.7)$ & $(8.7)$ & $(9.0)$ & $(19.7)$ & $(19.5)$ & $(19.7)$ \\
\hline 14 & 141 & 9 & 9 & 10 & 33 & 30 & 32 \\
& & $(6.4)$ & $(6.4)$ & $(7.9)$ & $(23.4)$ & $(21.3)$ & $(22.7)$ \\
\hline 15 & 65 & 3 & 2 & 3 & 8 & 7 & 7 \\
& & $(4.6)$ & $(3.7)$ & $(4.6)$ & $(12.3)$ & $(10.8)$ & $(10.8)$ \\
\hline 16 & 42 & 2 & 2 & 2 & 6 & 4 & 6 \\
& & $(4.8)$ & $(4.8)$ & $(4.8)$ & $(14.3)$ & $(9.5)$ & $(14.2)$ \\
\hline & 1598 & 169 & 174 & 173 & 327 & 316 & 293 \\
& & $(10.5)$ & $(10.8)$ & $(10.8)$ & $(20.5)$ & $(19.8)$ & $(18.4)$ \\
\hline
\end{tabular}

(TABLE -2)

PREVALENCE OF OBESITY AND OVER WEIGHT GIRLS

Obese Girl

\begin{tabular}{|c|c|c|c|c|c|c|c|}
\hline Age & $\begin{array}{c}\text { No of } \\
\text { Girls }\end{array}$ & Tim J. Cole Pts & $\begin{array}{c}\text { NHANES-1 } \\
\text { References }\end{array}$ & Eliz HPA & Tim J. Cole & NHANES & EHPA \\
\hline 10 & 117 & 7 & 7 & 5 & 34 & 34 & 29 \\
& $(5.9)$ & $(5.9)$ & $(4.3)$ & $(29.0)$ & $(29.5)$ & $(24.8)$ \\
\hline 11 & 278 & 19 & 19 & 18 & 65 & 61 & 61 \\
& & $(6.8)$ & $(6.8)$ & $(6.5)$ & $(23.4)$ & $(2.9)$ & $(21.9)$ \\
\hline 12 & 239 & 14 & 14 & 16 & 58 & 56 & 57 \\
& & $(5.8)$ & $(5.8)$ & $(6.7)$ & $(24.3)$ & $(23.4)$ & $(23.8)$ \\
\hline 13 & 168 & 3 & 3 & 5 & 27 & 25 & 21 \\
& & $(1.8)$ & $(1.8)$ & $(3.0)$ & $(16.7)$ & $(14.9)$ & $(12.5)$ \\
\hline 14 & 89 & 3 & 3 & 5 & 13 & 13 & 15 \\
\hline
\end{tabular}


Screening obesity in Adolescents

\begin{tabular}{|c|c|c|c|c|c|c|c|}
\hline & & $(3.4)$ & $(3.4)$ & $(5.6)$ & $(14.6)$ & $(14.6)$ & $(16.8)$ \\
\hline 15 & 43 & 1 & 1 & 3 & 5 & 5 & 7 \\
& & $(2.3)$ & $(2.3)$ & $(7.0)$ & $(11.6)$ & $(11.6)$ & $(16.3)$ \\
\hline 16 & 38 & NIL & NIL & Nil & 3 & 2 & 2 \\
& & & & & $(7.9)$ & $(5.3)$ & $(5.3)$ \\
\hline & 972 & 47 & 47 & 52 & 205 & 196 & 192 \\
& & $(4.8)$ & $(4.8)$ & $(5.4)$ & $(21.01)$ & $(20.16)$ & $(19.8)$ \\
\hline
\end{tabular}

(TABLE-3)

NUTRITIONAL STATUS OF ADOLESCENT BY EHPA-BOYS

\begin{tabular}{|c|c|c|c|c|c|}
\hline Age & No.of Boys & Obese > 25 BMI & \begin{tabular}{|c} 
Overweight $>22-$ \\
25 BMI \\
\end{tabular} & $\begin{array}{c}\text { Normal } \\
15-22 \text { BMI } \\
\end{array}$ & $\begin{array}{l}\text { Under weight/ } \\
\text { C.ED. }<15 \text { BMI } \\
\end{array}$ \\
\hline 10 & 174 & $\begin{array}{c}29 \\
(16.7)\end{array}$ & $\begin{array}{c}36 \\
(20.7)\end{array}$ & $\begin{array}{c}72 \\
(41.4)\end{array}$ & $\begin{array}{c}37 \\
(21.3)\end{array}$ \\
\hline 11 & 309 & $\begin{array}{c}32 \\
(10.3)\end{array}$ & $\begin{array}{c}46 \\
(14.9)\end{array}$ & $\begin{array}{c}186 \\
(60.1)\end{array}$ & $\begin{array}{c}45 \\
(14.6)\end{array}$ \\
\hline 12 & 456 & $\begin{array}{c}57 \\
(12.5) \\
\end{array}$ & $\begin{array}{c}99 \\
(21.7) \\
\end{array}$ & $\begin{array}{c}268 \\
(58.7) \\
\end{array}$ & $\begin{array}{c}32 \\
(7.1)\end{array}$ \\
\hline 13 & 411 & $\begin{array}{c}37 \\
(9.0)\end{array}$ & $\begin{array}{c}81 \\
(19.7)\end{array}$ & $\begin{array}{c}266 \\
(64.7)\end{array}$ & $\begin{array}{c}27 \\
(6.6)\end{array}$ \\
\hline 14 & 141 & $\begin{array}{c}10 \\
(7.09)\end{array}$ & $\begin{array}{c}32 \\
(22.7)\end{array}$ & $\begin{array}{c}90 \\
(63.8)\end{array}$ & $\begin{array}{c}9 \\
(6.4)\end{array}$ \\
\hline 15 & 65 & $\begin{array}{c}3 \\
(4.6)\end{array}$ & $\begin{array}{c}7 \\
(10.8)\end{array}$ & $\begin{array}{c}55 \\
(84.6)\end{array}$ & 0 \\
\hline 16 & 42 & $\begin{array}{c}2 \\
(4.8)\end{array}$ & $\begin{array}{c}6 \\
(14.2)\end{array}$ & $\begin{array}{c}34 \\
(80.9)\end{array}$ & 0 \\
\hline & 1598 & $\begin{array}{c}170 \\
(10.8)\end{array}$ & $\begin{array}{c}307 \\
(18.4)\end{array}$ & $\begin{array}{c}971 \\
(61.4)\end{array}$ & $\begin{array}{l}150 \\
(9.4)\end{array}$ \\
\hline
\end{tabular}

(TABLE-4)

NUTRITIONAL STATUS OF ADOLESCENT BY EHPA- GIRLS

\begin{tabular}{|c|c|c|c|c|c|}
\hline Age & $\begin{array}{l}\text { No.of } \\
\text { Girls }\end{array}$ & Obese > 25 BMI & $\begin{array}{c}\text { Overweight }>22- \\
25 \text { BMI } \\
\end{array}$ & Normal 15-22 BMI & $\begin{array}{l}\text { Under weight/ } \\
\text { C.ED.< } 15 \text { BMI }\end{array}$ \\
\hline 10 & 117 & $\begin{array}{c}5 \\
(4.3)\end{array}$ & $\begin{array}{c}29 \\
(24.8) \\
\end{array}$ & $\begin{array}{c}60 \\
(51.5)\end{array}$ & $\begin{array}{c}23 \\
(19.6)\end{array}$ \\
\hline 11 & 278 & $\begin{array}{c}18 \\
(6.5)\end{array}$ & $\begin{array}{c}61 \\
(21.9)\end{array}$ & $\begin{array}{c}174 \\
(62.6)\end{array}$ & $\begin{array}{c}25 \\
(9.0)\end{array}$ \\
\hline 12 & 239 & $\begin{array}{c}16 \\
(6.7)\end{array}$ & $\begin{array}{c}57 \\
(23.8) \\
\end{array}$ & $\begin{array}{c}150 \\
(62.8)\end{array}$ & $\begin{array}{c}16 \\
(6.7)\end{array}$ \\
\hline 13 & 168 & $\begin{array}{c}5 \\
(3.0)\end{array}$ & $\begin{array}{c}21 \\
(12.5)\end{array}$ & $\begin{array}{c}133 \\
(79.2)\end{array}$ & $\begin{array}{c}9 \\
(5.4)\end{array}$ \\
\hline 14 & 89 & $\begin{array}{c}5 \\
(5.6)\end{array}$ & $\begin{array}{c}15 \\
(16.8)\end{array}$ & $\begin{array}{c}69 \\
(77.5)\end{array}$ & 0 \\
\hline 15 & 43 & $\begin{array}{c}3 \\
(7.0)\end{array}$ & $\begin{array}{c}7 \\
(16.3)\end{array}$ & $\begin{array}{c}33 \\
(76.7) \\
\end{array}$ & 0 \\
\hline 16 & 38 & 0 & $\begin{array}{c}2 \\
(5.3)\end{array}$ & $\begin{array}{c}34 \\
(89.5) \\
\end{array}$ & $\begin{array}{c}2 \\
(5.3)\end{array}$ \\
\hline & 972 & $\begin{array}{c}52 \\
(5.3)\end{array}$ & $\begin{array}{c}192 \\
(19.7)\end{array}$ & $\begin{array}{c}653 \\
(67.2) \\
\end{array}$ & $\begin{array}{c}75 \\
(7.7)\end{array}$ \\
\hline
\end{tabular}

